\title{
The Case of the Fictitious Taxpayer: The Federal Taxpayer's Suit Twenty Years After Flast v. Cohen
}

\author{
Boris I. Bittker†
}

Reporter's Note: This opinion, or a reasonable facsimile thereof, is expected to appear in a forthcoming issue of the Federal Supplement.

\section{Frothinghiam V. Méllon, District Judge:}

I am asked in this case to decide whether à federal taxpayer's suit, challenging the constitutionality of an expenditure by the United States, may be maintained by a plaintiff who alleges that he is not now and never has been a taxpayer. Having attained this enviable status as a lifelong recipient of tax-exempt welfare payments, he states that he finds the prospect of receiving taxable income so unappealing that he intends to eschew any such opportunities; in keeping with this prediction, his complaint candidly admits that he is unlikely to pay any federal taxes in the future. In characterizing himself as a non-taxpayer, he would seem to invite a summary dismissal of his suit, were it not for the development in recent years of the concept of the fictitious-or, as some have termed it, the spurious-taxpayer's suit. Before discussing the application of this legal doctrine to the plaintiff before me, however, I think it well to review briefly the history of the federal taxpayer's suit since Flast $v$. Cohen. ${ }^{1}$

In the Flast case, the Supreme Court held that a federal statute authorizing expenditures that allegedly violated the establishment clause of the first amendment could be attacked by plaintiffs whose standing to sue rested solely on the fact that they paid federal income taxes:

† Southmayd Professor of Law, Yale Law School. Professor Bittker informs the Editors that the "immediate stimulus" for this article was "Standing: Taxpayers and Others" by Kenneth Culp Davis in Volume 35 of the Review. Professor Davis's response appears at page 375 of this issue.

1392 U.S. 83 (1968). See L. Jaffe, Judictal Control of Administrative Action 459-500 (1965); Davis, Standing: Taxpayers and Others, 35 U. Crr. L. REv. 601 (1968); Note, Taxpayers' Suits: A Survey and Summary, 69 YALE L.J. 895 (1960). 
[W] hold that a taxpayer will have standing consistent with Article III to invoke federal judicial power when he alleges that congressional action under the taxing and spending clause is in derogation of those constitutional provisions which operate to restrict the exercise of the taxing and spending power. The taxpayer's allegation in such cases would be that his tax money is being extracted and spent in violation of specific constitutional protections against such abuses of legislative power. Such an injury is appropriate for judicial redress, and the taxpayer has established the necessary nexus between his status and the nature of the allegedly unconstitutional action to support his claim of standing to secure judicial review. ${ }^{2}$

In the two decades since this "cornerstone of the law of standing"3 was laid down, the courts have erected upon it an imposing, if not always harmonious or universally-acclaimed, structure. Although predictions are perilous, the case before me may turn out to be the capstone of this architectural endeavor.

It will be recalled that the first plaintiff to bring a suit after the decision in the Flast case was a French businessman who was a passenger on a plane that, while en route from Paris to Montreal, was forced by engine trouble to land at Kennedy International Airport. Having spent the night in New York City, where he made several long distance telephone calls that were subject to federal excise tax, he sued the United States to restrain the expenditure of federal funds to maintain military bases located in Louisiana, alleging (in the language of the Flast case) that "his tax money" was being spent improperly because the Louisiana Purchase was an unconstitutionally ultra vires expansion of United States sovereignty. Without reaching the merits, the Supreme Court upheld a dismissal of his suit on the ground that an "accidental" taxpayer does not have a sufficient interest in the constitutionality of federal expenditures to justify a judicial resolution of his contention. This limitation on the taxpayer's suit became known as the "accidental taxpayer" exception.

As might perhaps have been foreseen in view of our strained relations with de Gaulle, a similar suit was filed within a few months by a second French businessman, who sought to take himself out of the "accidental taxpayer" category by alleging that he passed through Kennedy International Airport at least once a month on his way

\footnotetext{
2 Flast v. Cohen, 392 U.S. 83, 106 (1968).

3 "The narrow holding [of Flast v. Cohen] seems impregnable and seems destined to become a long-term cornerstone of the law of standing." Davis, supra note 1, at 601 .
} 
from Paris to Winnipeg and that he always bought a federally-taxed cocktail while waiting for his connecting plane. He buttressed these allegations with the charge that the inefficiency of a federal agency responsible for the operation of the airport caused frequent delays, so that he often bought more than one drink while, as he put it, "held in captivity" in New York City. This suit was dismissed on a broader theory than had been advanced against its predecessor, viz., that an alien who has not "entered" the United States by passing through the Customs and Immigration barrier at an international airport cannot be a "taxpayer." Citing numerous authorities, the Court said that a "tax" is a charge imposed by a government on persons enjoying the benefit of its protection, a status that is not attained by aliens before they have entered the country. Although the amount paid by the plaintiff was called a "tax," the Court said that "in truth and in reality it was a fee paid for assurance that the drink was not adulterated or mislabelled." Acknowledging that it is not always easy to determine whether a government-imposed liability is a "tax" or a "fee," the Court said that the consequences of permitting nonresident aliens to flood the courts with politically-inspired suits warranted an irrebuttable presumption that payments by nonresident aliens in such circumstances are "fees" rather than "taxes." This restriction on the federal taxpayer's suit became known as the "non-tax tax" doctrine.

Gallic persistence did not run out with this decision. The Court was soon confronted by a taxpayer's suit brought by a French corporation which, being engaged in business in the United States through a "permanent establishment," was required to pay federal income tax on its domestic business profits. The Supreme Court held that a legal entity owing its existence to the law of another sovereignty could not maintain a federal taxpayer's suit; such a suit presupposed, the Court held, a "single-minded" interest in enforcing the Constitution of the United States, an interest that could not be reconciled with a foreign entity's obligations to another sovereign. This development (the socalled "loyal taxpayer" doctrine) made it clear that the payment of taxes was, by itself, insufficient to qualify a plaintiff to maintain a federal taxpayer's suit; and it led some commentators to argue that the law of standing needed a better cornerstone.

While this academic dispute was being pursued in the law journals, however, the courts continued to explicate the "loyal taxpayer" doctrine, and in an important case it was applied to disqualify a United States corporation all of whose shareholders were aliens. This restriction, in turn, was elaborated by the courts to bar suits by United States corporations that, despite formal American ownership, were "con- 
trolled," directly or indirectly, by aliens. After a few years of experience with ad hoc judicial determinations of the existence vel non of proscribed foreign "control," Congress established an administrative agency-the Taxpayer's Suit Licensing Board-charged with the obligation of determining whether a corporation which wished to bring a taxpayer's suit against the United States was foreign-controlled.

This Board's zeal, which included the employment of Swiss informers to gain evidence of the complicity of Swiss banks in concealing foreign interests in United States corporations, was much resented by foreign governments; and this led the State Department in a notable case to "suggest" to the district court that it would be well to deny to all corporations the right to act as plaintiffs in federal taxpayer's suits, rather than continue the practice of judicial or administrative discrimination against foreign-controlled corporations. The "suggestion" was indignantly rejected as an attempted invasion of a purely judicial sphere; but the court reached the same result on the ground that it was "wholly anomalous" to permit corporations to act as plaintiffs in taxpayer's actions. The theory of the court was that corporate charters are granted by state legislatures to enable business groups to pursue business objectives; because "the business of a corporation is business and not politics," the court held that it had no standing to maintain a federal taxpayer's suit which, though based on a "pocketbook injury," never results in a money judgment to the injured party.

Although some commentators thought that this prohibition on corporate suits presaged the death of the "pocketbook injury" rationale as to all plaintiffs, arguing that it should be replaced by a "citizen interest" concept of standing, ${ }^{4}$ persistent judicial assertions that a financial loss was the basis of standing in federal taxpayers' suits led the government to seek an advantage in this orthodoxy, rather than its repudiation. Thus, in an important case, the Treasury counterclaimed against the plaintiff, alleging that he had underpaid his federal income taxes for the year in which he claimed taxpayer status and asking the court to decide this issue along with the taxpayer's constitutional claim. The Supreme Court expressed the opinion that a decision on the government's counterclaim would undermine the procedures decreed by Congress for assessing, determining, and collecting tax deficiencies; and it was held, accordingly, that a tax delinquency could not be used affirmatively, as a "sword," in a taxpayer's suit. In a later suit, the government sought to use an alleged tax delinquency defensively, as

4 Cf. Jaffe's concept of "public action," L. JAFFE, supra note I; and note that as early as 1960, it was asserted that taxpayers' suits have "functionally" become "citizens" suits." 69 YALE L.J. at 906. 
a "șhield," to bar the plaintiff from pursuing his taxpayer's suit until his tax liability was finally determined in the appropriate fashion. Even though the government was not asking for a money judgment by way of counterclaim in the taxpayer's suit, the Court rejected its assertion. In a similar vein, the courts refused to strike a financial balance even when the government offered to prove that the plaintiff was indebted to it for back taxes or other undisputed claims in an amount greater than the "dollars-and-cents" injury alleged by him in his taxpayer's suit.

Other decisions undermining the "pocketbook injury" theory of the taxpayer's suit can also be found by a diligent student of the reported cases. For example, in a case in which the government offered to refund a pro rata share of the offensive expenditure to the plaintiff, thus making him whole again, it was held that he could refuse the offer and press the case if he so desired. (The proposal was evidently made at a time when the statute of limitations would have prevented the institution of a new suit by another plaintiff.) Though not a class action, the suit was imbued with a public interest that would be frustrated, said the Court, if the government were allowed to "buy off" the plaintiff. From this holding, it was, of course, only a step to a determination that the action was a quasi-class suit, which could not be terminated by the plaintiff alone; since other potential plaintiffs might have refrained from suing in reliance on his initiative, they are entitled to be notified and to take over the suit, should the original plaintiff grow weary, at least if the statute of limitations would bar an independent action by them. In a case that was much debated in the law schools, this principle was applied to permit a suit to be transferred from an alien (disqualified by the "loyal taxpayer" doctrine) to a citizen, although the substituted plaintiff had himself been an alien when the case was begun. A taxpayer's suit is a public trust, said the Court in a much-quoted aphorism; to allow the trust res to evaporate for want of a qualified plaintiff is equivalent to allowing the government to take private property without just compensation. "While this Court sits," it was said, "we will not allow the government to work a forfeiture of a cause of action that arose through its own violation of the Gonstitution. Felonies may not be compounded!" This arresting language has been often repeated at bar association dinners.

In another series of cases, the courts were called upon to determine the ambit of the term "taxpayer," as used in the shorthand phrase "taxpayer's suit.". In the first case in this series, the court held that a plaintiff who had paid federal income taxes for past years qualified as a "taxpayer" even though his income in the year the suit was commenced was below the exemption level. On the assumption-not chal- 
lenged by the government-that the federal income tax is a permanent institution, the court held that the plaintiff's "career" as a taxpayer had been interrupted, rather than terminated, by the low level of income received by him in the year of the suit. Although this "dormant taxpayer" doctrine seemed to conflict with the requirement that the plaintiff suffer a "pocketbook injury," the courts pointed out that money is fungible, and from this fact it was asserted that the offensive expenditures might have been financed with the "tax money" contributed by the plaintiff in past years. Commentators objected to this theory, arguing that the Treasury was running deficits throughout the years in question, so that no "tax money" taken from the plaintiff in one year could have been used to finance expenditures in later years. Before this objection was presented to the courts for decision, however, the "dormant taxpayer" doctrine fell into desuetude or, more precisely, was merged into the broader "incipient taxpayer" doctrine.

The "incipient taxpayer" doctrine emerged from a group of cases in which the plaintiffs alleged that by virtue of youth, early losses in establishing a business, or other circumstances, they had not yet paid any federal taxes, but that they could reasonably be expected to become taxpayers at a later time. After initial fumbling, the courts held that such an allegation (if not disproved by the government) was sufficient to establish a "dollars-and-cents" injury: the plaintiff will have to carry some of the burden of present expenditures, through the increased government debt (or failure to reduce the debt) resulting from these expenditures, and also because expenditure programs-once instituted-have a momentum that encourages if it does not insure their continuation. (To be sure, the Supreme Court had said in the Frothingham case $^{5}$ that the effect of current federal expenditures on future taxation was too "remote, fluctuating and uncertain" to create standing to sue, but that was before the Flast case.) The Court acknowledged that it was paradoxical to describe a non-taxpayer as a taxpayer, but said that the concept of a quasi-this or an incipient-that was not unknown to the law. It also asserted that labels should not be controlling, pointing out that a successful taxpayer's suit will in any event be of benefit only to future taxpayers (by lowering the level, possibly, of future taxes), since it never results in a refund of past taxes. As already suggested, the "incipient taxpayer" doctrine swallowed up the "dormant taxpayer" doctrine: if a suit can be maintained by one who has not yet helped to finance his government's operations, it can

5 Frothingham v. Mellon, 262 U.S. 447, 487 (1923). 
a fortiori be maintained by an incipient taxpayer who has also made payments in past years. Indeed, some scholars suggested that the plaintiff should always be required to prove that he expects to pay taxes in the future, and that an allegation of past tax payments should be stricken as irrelevant.

The next step in expanding the concept of "taxpayer" was taken in a case whose plaintiff derived all of his income from tax-exempt state and municipal bonds, and who baldly asserted that he did not intend to alter this practice in the future. His claim to taxpayer-status was based on the "incipient taxpayer" doctrine, since he asserted that if the expenditures that he challenged on constitutional grounds were allowed to continue, Congress might well decide to expand the tax base by requiring state and municipal bond interest to be included in taxable income. Accepting this line of argument, the Court held that he was a "potential" incipient taxpayer, whose pocketbook was threatened in a more-than-speculative fashion by the expenditures he desired to attack. It was noted that no one can be sure that he will pay taxes in the future, even if his financial profile fits within today's tax law; since the currently exempt plaintiff has no vested interest in his immunity, the offensive expenditure, if not terminated, may kill his golden goose.

In deciding for the plaintiff on this ground (the "golden goose," or "last straw," doctrine), the Court was able to avoid ruling directly on a second line of argument advanced on his behalf, viz., that he was "in effect" a taxpayer since, to obtain tax immunity, he had accepted a lower rate of return on his investments than he would have realized on taxable investments. There should be no distinction, he argued, between a person who takes in $\$ 100,000$ in taxable interest and pays out $\$ 40,000$ in federal taxes, and a person who takes in $\$ 60,000$ net of taxes because he invests solely in tax-exempt securities. After pointing out that this ground was unnecessary in view of the plaintiff's status as a "potential incipient taxpayer," the court went on to say that he had failed to prove that his net income had in fact been diminished by his exemption; and this dictum left a residue that we must contend with now, since it implied that a person who bears the burden of taxation is a taxpayer even though he pays nothing directly to the government.

This implication, which has been dubbed "the indirect taxpayer doctrine," soon became grist for the judicial mill. A plaintiff alleged that he bore the burden of federal taxation because the cost of goods and services purchased by him reflected, at least in part, the taxes imposed on the purveyors with whom he dealt. Admitting that expert 
opinion is not in harmony on the extent of tax-shifting, he argued that some shifting of the burden was likely; and he asked therefore to be allowed to maintain a taxpayer's suit on the ground that unconstitutional federal expenditures damaged his material well-being in a real sense, even though the burden might have been diluted because shifting is not complete. His claim, in short, was that "standing" should be viewed as "running with" the tax burden. The government responded that the extent of shifting was indeed uncertain, and-of greater import-that the plaintiff might himself be passing the burden on to his customers. But the latter point could be offered against any taxpayer, and if accepted would prevent anyone from qualifying as a plaintiff in a taxpayer's suit. The Supreme Court concluded, therefore, that a person bearing the burden of taxation could institute a taxpayer's suit, and it coupled this conclusion with a presumption that any purchaser of goods and services in the domestic economy bears, albeit indirectly, the burden of taxation unless the contrary is shown by the clear preponderance of the evidence. ${ }^{8}$

This decision-widely hailed as a triumph of realism over conceptualism-was thought to mean that everyone in our society could qualify as a plaintiff in a taxpayer's suit; and this result was approved by many commentators because it permitted the taxpayer's suit to remain as a "cornerstone of the law of standing,"" while purging it of the invidious implication, as offensive as a property qualification for voting, that only the rich are entitled to complain about government expenditures.

The case before me, however, reminds us that there are persons in America who cannot qualify as dormant taxpayers, incipient taxpayers, potential incipient taxpayers, or indirect taxpayers. This plaintiff cannot bring himself within any of these categories because the relief pay-

B In thus equating the economic burden of a tax with its legal incidence, the Court may have overlooked First Agricultural Nat'1 Bank v. State Tax Commission, 392 U.S. 339,346 (1968), where it noted that the lower court had held that a sales tax imposed on a vendor of personal property cannot be regarded as a "tax" on the vendee, even if the vendor "decides to pass the burden of the tax on to [the vendee] through an increased price." This holding was not controlling, however, since the Court found, in the end, that the "legal incidence," not merely the economic burden, of the tax in question was on the vendee, a national bank. Moreover, one must not overlook the painful dilemma in which the Court found itself in that case: although the burden of taxation falls at least in part on many persons with whom the technical taxpayer has business dealings, the Court obviously could not have stricken down all taxes to the extent that, sooner or later, they might be borne by a national bank. It was forced, therefore, either to apply McCulloch $v$. Maryland to discriminatory taxes only, or to cling to a conceptual distinction between the "legal incidence" of a tax and its economic consequences-unless it was prepared to join the dissenters in re-examining the character of national banks.

7 Supra note 3. 
ments by which he has been, is, and expects to be supported are nontaxable and are geared to the cost of living; thus, he does not feel the burden of taxation; since his benëfits escalate in exáct measure to increases in the cost of living. Moreover, the escalation clause has been held to constitute a "vested right" of which the plaintiff cannot be deprived without just compensation, and it embraces not only the level of payments but also their immunity from taxation. If anyone is barred from acting as a plaintiff in a taxpayer's suit, therefore, it is the person before me.

In support of his request to be recognized as a legitimate claimant in a federal taxpayer's suit, however, the plaintiff argues that he will suffer a "pocketbook injury" if the allegedly improper expenditures are not terminated, because-he alleges-Congress will be less willing to increase the level of his welfare benefits; conversely, he asserts, a reduction of the expenditures in question will make it that much easier for his congressional champions to wage a successful campaign on his behalf. There is, he candidly admits, no assurance that Congress will in fact expand the welfare program if it is compelled to reduce the level of expenses elsewhere, but he points out that the orthodox taxpayer's suit is equally speculative in its impäct: damages are never awarded to the plainitiff, and it is possible that Congress will spend "his tax money" in other, unassailable programs if the one he attacks is held to be unconstitutional.

The plaintiff also makes the interesting point that if tax allowances (e.g., percentage depletion and the exemption of state and municipal bond interest) are properly regarded as the equivalent of expenditures by the federal government ( $a$ theory that is accepted by many respected authorities), ${ }^{8}$ the converse is also true, viz., a federal refusal to máke an expenditure for a groúp of citizens is tantamount to taxing them. This leads him to assert that a congressional refusal or failure to increase welfare payments should be viewed by this court as the functional equivalent of a tax on him and others similarly situated, and that they should therefore be regarded as taxpayers.

Pursuing further his argument that unconstitutional expenditures should be presumed to affect him adversely, the plaintiff asks that jurisdiction in his case be patterned on the familiar common law writ of quo minus, the device by which the jurisdiction of the English

8 See, e.g., 113 Cong. REc. 36,404 (1967) (remarks of Congressman Mills). The impact of the theory that tax exemptions are functionally equivalent to expenditures has been seen in several federal taxpayer's suits in which taxpayers have attacked the statutory allowances enjoyed by other taxpayers, asserting that these allowances should be treated as expenditures. Because these cases are still pending, I comment no further on the issue. 
Court of Exchequer was expanded to embrace private lawsuits, on the theory that if the injured party's loss was not redressed, his ability to pay his feudal dues or other debts to the Crown would be impaired. ${ }^{9}$ In time, the allegations that the plaintiff requesting Exchequer jurisdiction owed something to the Crown, and would be unable to pay it, could not be traversed by the defendant.

The analogy is so apt, and my desire to be governed by precedent so great, that I would be tempted to decide the case in the plaintiff's favor on this ground, were it not for a second line of argument advanced by him, which I find even more persuasive. This claim is that poverty, and poverty alone, is the reason why he is not a taxpayer of any species (ordinary, dormant, incipient, potential incipient, or indirect); if he were a property owner, he would either pay taxes on his income or bear the burden of taxation on purchasing the goods and services needed to maintain his assets. Surely the due process clause forbids such an invidious distinction-totally unrelated to the plaintiff's personal merits-as this. ${ }^{10}$

What we must ask of a plaintiff in a taxpayer's suit is that his credentials give us confidence:

that the questions will be framed with the necessary specificity, that the issues will be contested with the necessary adverseness and that the litigation will be pursued with the necessary vigor to assure that the constitutional challenge will be made in a form traditionally thought to be capable of judicial resolution. ${ }^{11}$

Once we recognize that an ordinary plaintiff in a federal taxpayer's suit has no greater financial interest in his complaint than the hope that his future tax liability be lower by some small amount if the objectionable expenditures are prohibited, it becomes clear that the interest of the plaintiff before me in effective and vigorous advocacy is no less substantial. I hold, therefore, that he is entitled to institute a taxpayer's suit.

It has been urged that to take this final step would be to convert the federal taxpayer's suit into the "public action" advocated some decades ago by Professor Jaffe. ${ }^{12} \mathrm{I}$ am, of course, aware of the important differences between the taxpayer's suit, based as it is on a "pocketbook injury" to the plaintiff, and the so-called public action, which would

9 Wurzel, The Origin and Development of Quo Minus, 49 YALE L.J. 39 (1939).

10 See Griffin v. Illinois, 351 U.S. 12 (1955).

11 Flast v. Cohen, 392 U.S. 83, 106 (1968).

12 L. JAFFE, supra note 1. 
permit any self-appointed protector of the community to clutter up the courts with lawsuits. But my decision, quite obviously, will do no more than permit federal taxpayer's suits to be brought by those who are qualified to bring them. A plaintiff will have to allege that he has paid, is paying, or will pay federal taxes; or that he bears the burden of federal taxation; or that it would be a denial of due process to prevent him from instituting a taxpayer's suit. My decision, therefore, does no injury to the "cornerstone of the law of standing," but merely unveils its true contours. If they turn out to be co-extensive with Professor Jaffe's "public action," so be it. It will not be the first time that a legal doctrine, on full examination, was found to coalesce with an apparently conflicting legal principle.

The motion to dismiss the complaint is denied. 